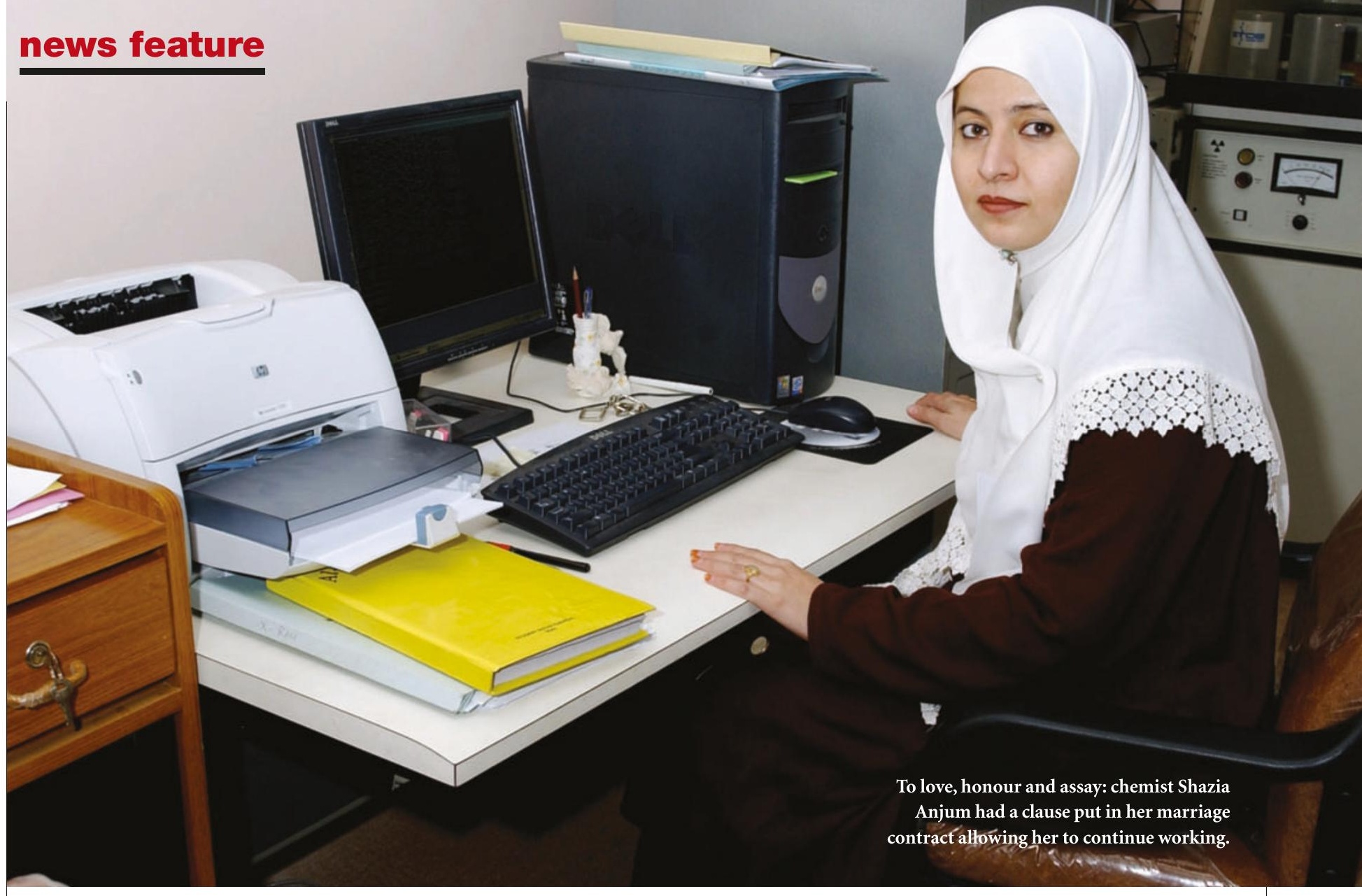

\title{
Women at work
}

Pakistan's traditional ways have blocked many women's careers in science. But, as Ehsan Masood discovers, women are now fighting for their rights, both in life and in research.

\section{"W} hen I was doing my $\mathrm{PhD}$, my husband and children would come to the department if I wanted to stay after 9 p.m.," recalls Zahida Maqsood, a professor of chemistry at the University of Karachi. This wasn't just to keep her company; nor to hassle her to come home and cook. In most Pakistani families, women are simply not allowed to work late alone, or to socialize after work with male colleagues. Even today, some 25 years since Maqsood's graduation, things are much the same. "If my students want to stay late, their families come and wait for them outside on the lawn," says Shakeel Farooqi, assistant professor of genetics at Karachi.

But the winds of change are beginning to stir. Secular women's liberation movements have had very little impact in Pakistan. But the country, like many predominantly Muslim states, is witnessing the birth of Islamic feminism, in which women are demanding rights that they say Islam accords to them. It is being fuelled in part by more women going to schools and universities, and also by a generation of women evangelists such as Farhat Hashmi, founder of the worldwide Al-Huda International Welfare Foundation, which teaches women about Islam. Hashmi's lectures draw crowds of up to 10,000 women.

\section{Employment rights}

The effects are being felt throughout the country - including in its labs. Chemist Shazia Anjum, for example, is using her Muslim marriage contract to ensure that her science career moves forward. When she married she insisted upon a 'right to work' clause that would prevent her husband or his family from stopping her getting a job. Such legally binding, bespoke clauses are allowed in Muslim marriages, and can be inserted by the bride or groom; a woman may ask to be paid for her housework, for example. But a combination of low levels of female literacy and established social conventions mean that few of Pakistan's women are aware of these rights. Even fewer would think of using them. For Anjum, it has made possible her assistant professorship in chemistry at the International Centre for Chemical Sciences at the University of Karachi.

Some, including a former head of Pakistan's Medical Research Council, claim to have had even fewer problems advancing their professional lives. Tasleem Akhtar comes from the North-West Frontier province, which is governed by an alliance of Islamic parties and is better known in the West for its role in nurturing the Taliban. Yet she still made it to the top job in medical research without, as she puts it, "needing to play golf with the minister for health". She claims never to have felt the cold pressure of a glass ceiling; nor did she find opposition from within her own family. "I was allowed to study in the United Kingdom, no problem," she says. "Instead of being forced to marry, daughters from poor families are often encouraged to get an education and earn a living for the rest of the family. It is in lowerand upper-middle-class families where you find the pressure to marry instead."

Although Anjum and Akhtar's experiences are a sign of changing times, many cultural barriers remain. Women rarely live alone in Pakistan, unless they are widowed or 
divorced. Most live instead in extended families, in which parents, husbands and brothers often have the final say in decisions affecting their lives. Women cannot apply for a university place, a public-sector job or even a passport without completing a section on an application form that asks them for details of their father or husband. Most are forbidden by families to travel long distances without a male escort. Few drive cars beyond the limits of a handful of large cities and none ride bicycles or motorbikes on public roads. Women cannot marry without the written consent of a male, usually their father.

\section{Liberal attitude}

This kind of life may look painfully restrictive to Western eyes, but women's rights is now a cause with top-level backing from no less than President Pervez Musharraf and the chairman of Pakistan's Higher Education Commission, Atta-ur-Rahman, who was Anjum's PhD supervisor. Some of this support comes in the form of minor initiatives, such as encouraging higher-education institutions to provide women-only transport to ferry them safely home late at night. Other actions are much more significant. Musharraf, for example, has piloted a new law that formally recognizes 'honour killings' as a crime in their own right — punishable by death or life imprisonment. The killings, in which families in some rural areas punish women with death if, for example, they marry without permission or have premarital sex, results in about 1,000 deaths every year.

The statistics for girls in schools and universities are also improving. In 1991, women accounted for one in five of the 60,000 students in the country's public universities. By 2001, their numbers had reached a third of the student population of 118,000 .

Pakistan's overall efforts in science are on the increase, too. The country's military dictatorships have historically been more generous to scientists than civilian administrations have been, and the Musharraf regime is no different. Science spending has multiplied 60-fold since 1999 and a major programme is under way to upgrade laboratories and boost the numbers of PhDs (see Nature 432, 273-274;2004).

The results of these changes can be seen at the universities in Pakistan's larger cities. At the Usman Institute of Technology in Karachi, a dozen researchers - male and female, young and old - gather to discuss these developments, and how women can make their voices heard in science. Anjum attends, dressed in what has become the international

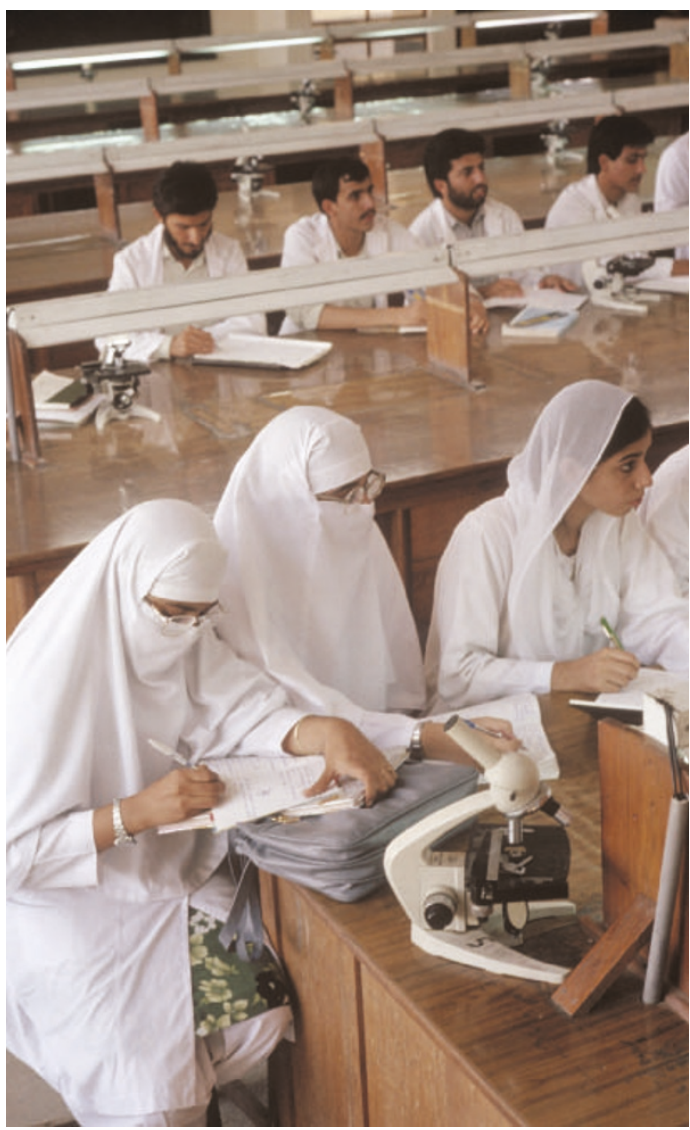

Hidden talents: chemistry students in Peshawar are among the rising numbers of women studying science.

uniform of Muslim feminism: a long, loosefitting coat and hijab, the scarf that covers hair and head. But she is silent at the beginning of the two-hour meeting. Girls from most Pakistani households are mostly not encouraged to voice opinions in public; in addition, a tradition of deference and respect for older people means that they are unlikely to disagree with the views of senior colleagues present around the table. The ice only really beings to melt when the group gets on to the question of women needing the permission of a male relative to stay late in the lab. Most of the women acknowledge that they cannot work late without the consent of their parents, husbands or in-laws. The men nod in agreement.

\section{Solo projects}

Such attitudes present a significant obstacle to researchers working in rural or remote parts of the country. These places may provide a gold-mine of unexplored opportunities for research in areas such as geology and geophysics, hydrology and biological diversity. But university research managers are wary of assigning such projects to women.

For this reason, says Nayyer Alam Zaigham, a geologist at the University of Karachi, his department has produced just one female $\mathrm{PhD}$ in seismology in the past 50 years. "In North America or Europe, you may be able to travel alone," he says. "But in my country, women have to be accompanied. It's a social thing. I cannot send women out to remote areas on their own. I cannot always go with them. And I cannot always arrange an escort. This is a big problem.”

Quddusi Kazmi, director of the Marine Reference Collection at the University of Karachi, has plenty of experience of men telling her what she can and cannot do. When she was a student contemplating a research career in marine zoology, she says, one of her professors told her: "We can't allow a lady to do marine zoology. You have to go to the field. You have to go to the sea at odd times. Will your parents allow this?"

Kazmi got her degree anyway, although she says that she will never be allowed to learn how to swim or dive to assist her research. Bathing in public is considered immodest for women, and publicly funded women-only swimming does not exist anywhere in Karachi, she says. While she was doing her degree, collecting specimens meant wading out to sea at low tide and rushing back to shore before the tide came in. "We would feel awkward," she recalls. "People would stare at us as if we were animals." These days, she has to hire fieldmen to do the actual collection.

The good news is that the percentage of female university lecturers has been steadily rising - from $13 \%$ in 1990 to $24 \%$ in 2002. The female student population of the two largest universities is high: $67 \%$ in Karachi and $50 \%$ at the University of the Punjab. Even at universities in the more rural provinces of Sindh and Balochistan, one third of the students are women.

It will be tough to get women into an equal position in the lab, admits Rahman. From their earliest years, men and women are discouraged from mixing, he notes. Even in public places, men and women automatically line up in separate queues, and public transport tends to be segregated. But Rahman is convinced that mixed labs are better for research. Having women work alongside men, he says, leads to obvious improvements in the atmosphere of a lab or research institution. "It does a lot of good. We find that men behave better, dress better and are more punctual," he says.

Rahman's director of public relations, Mamoona Amjed, who is sitting in on the interview, breaks into a laugh when she hears this and asks jokingly whether the comment applies to the minister himself. The fact that a Pakistani female civil servant (admittedly, a senior one) can tease a minister in the presence of a journalist is a small sign, perhaps, that life for tomorrow's women may be easier than for those of yesterday.

Ehsan Masood is a freelance journalist based in London. 